\title{
The Impact of Environmental Certification on Hotel Guest Ratings
}

Cornell Hospitality Quarterly

20I4, Vol. 55(I) 40-5I

(C) The Author(s) 2013

Reprints and permissions:

sagepub.com/journalsPermissions.nav DOI: 10.1 | 77//19389655/3503488

cqx.sagepub.com

\author{
Angel Peiró-Signes ${ }^{1,2}$, María-del-Val Segarra-Oña ${ }^{1,2}$, Rohit Verma', \\ José Mondéjar-Jiménez ${ }^{3}$, and Manuel Vargas-Vargas ${ }^{3}$
}

\begin{abstract}
In this article, we analyze the impact on hotels of the ISO I400I environmental certification system from the customers' perspective. Based on a comparison of customer ratings of 6,850 hotels in Spain with and without ISO I400 I certification, overall guests rate the hotels with ISO I400I certification higher than those without the certification. These results are stronger for hotel comfort and hotel services compared with other hotel attributes. Moreover, the most significant differences were found in the upscale four-star hotels. While the study does not reveal causes for these findings, the implication is that the highest end five-star luxury hotels do not gain distinctive differentiation by having the ISO I400 I certification, while for three-star hotels, guests' price sensitivity overrides environmental concerns. At the four-star level, however, hotels seem to be able to gain a distinct market advantage from environmental certification. For all hotels, the management discipline provided by ISO I400 I can provide a competitive advantage.
\end{abstract}

\section{Keywords}

environmental certification, customer ratings; ISO I400 I, Spanish hotel industry

Numerous studies of the hotel industry have shown that commitment to environmental practices improves hotels' financial performance (e.g., Álvarez Gil, Burgos Jiménez, and Céspedes Lorente 2001; Claver-Cortés, Molina-Azorín, and Pereira-Moliner 2007; López-Gamero, Claver-Cortés, and Molina-Azorín 2011; Molina-Azorín, Claver-Cortés, López-Gamero, et al. 2009; Sánchez-Ollero, García-Pozo, and Marchante-Lara 2011; Segarra-Oña et al. 2012; Tarí et al. 2010; Tzschentke, Kirk, and Lynch 2008; Zhang, Joglekar, and Verma 2012c). More critically, research has shown a growing consensus on the most sustainable practices for the hotel industry (e.g., Ferrari, Mondéjar-Jiménez, and Vargas-Vargas 2010; Goodman 2000; Hsieh 2012; H. $\mathrm{Hu}$, Parsa, and Self 2010; Kasim 2009; Sloan, Legrand, and Chen 2012). Despite the industry's progress in becoming sustainable, hotels still struggle with the most effective way to promote their green status. One mechanism for such notice is a third-party declaration, and thus formal certification is slowly becoming a common approach for hotels to demonstrate their commitment to sustainability (Font 2002; Mensah 2006; Nicholls and Kang 2012; Rodríguez-Antón et al. 2012; Sloan et al. 2009; Van Rheede, Blomme, and Tromp 2010). Among the third parties offering certification are online travel agencies such as Travelocity.com, which has started "green-flagging" hotels based on their environmental certifications (see http://www.travelocity.com), and the U.S. Green Building Council, which offers Leadership in Energy and Environmental Design (LEED) certification.
Another certification growing in importance is ISO 14001, which is an international standard for sustainable operation. ISO 14001 certification has two potential benefits. One is the improvement in operations due to following the certification's methodical standards. These benefits extend to internal or operational improvement (e.g., W. W. Chan 2009; W. W. Chan and Ho 2006; E. S. W. Chan and Wong 2006), marketing-related improvement (e.g., Matuszak-Flejszman 2009; Zeng et al. 2011), and financial performance improvement (e.g., Klassen and McLaughlin 1996; Molina-Azorín, Claver-Cortés, Pereira-Moliner, et al. 2009; Segarra-Oña et al. 2012). The other expected benefit of certification is the third-party sustainability credential, which should improve sales. However, we know of no studies that have evaluated the relationship of certification with customer satisfaction in the form of guest ratings (as a precondition of increased sales). In that regard, post-stay guest ratings are generally considered to be a good proxy for customer satisfaction and loyalty (Gustin and Weaver 1996;

'Cornell University, Ithaca, NY, USA

${ }^{2}$ Universitat Politècnica de València, Spain

${ }^{3}$ Universidad de Castilla-La Mancha, Albacete, Spain

\section{Corresponding Author:}

María-del-Val Segarra-Oña, Management Department, Universitat Politècnica de València, 7D building, Cno. de Vera s/n, 46022 Valencia, Spain

Email: maseo@omp.upv.es 
Ramanathan 2012). For example, a recent report from the Cornell Center for Hospitality Research (Anderson 2012) has demonstrated that higher online guest ratings lead to higher occupancy, room rates, and market share. To fill this conceptual gap, in this study we test whether environmental certifications such as ISO 14001 are related to guest ratings as a proxy for satisfaction.

We believe that this study has important implications for hotel managers, in part because one theory suggests that a hotel's environmental commitment (demonstrated in this case by certification) leads to higher guest ratings, and by implication higher rates and occupancy. In this study, we analyze data from Booking.com regarding guests' experience at the hotels, including housekeeping accuracy, and the hotel's comfort, services, staff, and total value.

\section{Background and Objectives}

The ISO 14001 environmental management system (EMS) is an international quality standard developed in 1996 by the International Standards Organization. ${ }^{1}$ The aim of ISO 14001 is development of effective EMS that can be applied to any type of company. According to ISO, the ISO 14001 standard specifies a path for the continuous improvement and the control of a firm's environmental performance. It enables a company to identify and control the environmental impact of its products, processes, and services and also to improve its environmental performance.

The ISO 14001 standards are also consistent with the definition of a "green" hotel put forth by the American "Green" Hotel Association: "green" hotels are environmentally friendly properties whose managers are eager to institute programs that save water, save energy, and reduce solid waste - while saving money. ${ }^{2}$ Because ISO 14001 provides assurance to company management and employees as well as external stakeholders that environmental impact is being measured and improved (ISO Central Secretariat 2009), the standard has used as a proxy for environmental orientation in many research projects (e.g., Lee et al. 2010; Lockyer 2003; Millar and Baloglu 2011; Zhang, Joglekar, and Verma 2012a, 2012b).

Studies of consumer perceptions toward green practices in the hospitality industry have generally shown that environmental practices are positively related to performance through the mediating effect of higher customer satisfaction and loyalty (Kassinis and Soteriou 2003). They also show ecolabels and environmental certifications as a source of differentiation that leads to enhanced customer awareness of restaurants' and hotels' environmental efforts (Schubert et al. 2010; Zhang et al. 2012b).

Environmental certifications provide a signal to guests and a way of informing them what an environmentally conscious hotel does. Until recently, consumers tended to be skeptical of ecolabels but there is now greater acceptance that a green certification label can have positive influence on a hotel's performance. D'Souza, Taghian, and Lamb (2006), for instance, examined visitors' preferences and concluded that visitors preferred "eco-efficient" planning options to business-as-usual scenarios, although that support varied by market segment (Kelly et al. 2007). According to Millar (2009), green certification has become the most influential attribute when measuring preferences for green hotel attributes from the clients' point of view.

However, we have seen little hotel research that specifically evaluates the effects of ISO 14001 on guests' hotel ratings. Given that research generally is supportive of positive impact of EMS, we propose the following hypothesis:

Hypothesis 1 (H1): Hotels with the ISO 14001 standard environmental certification receive higher customer ratings compared with the hotels without ISO 14001 certification.

To explore the linkages between the implementation of ISO 14001 and the various determinants of customer satisfaction and service quality (Hsieh 2012; Ramanathan 2012; Su and Sun 2007), we tested guests' satisfaction with specific hotel features. In addition to location, numerous features and amenities have been found to affect guest satisfaction, including employee attitude, rooms, and prices (Millar 2009); brand name and reputation, physical property, value for money, and guestroom design (Dubé et al. 1999; Dubé and Renaghan 1999); services (Ming-Hsiang, Gon, and Jeong 2005; Wong and Chi-Yung 2002); housekeeping (Gunderson, Heide, and Olsson 1996); hotel comfort (C. Hu and Hiemstra 1996); and hotel services (Verma 2007).

The ISO 14001 standard places the responsibility for the EMS on the organization's top management, and its similarities with management standards in ISO 9001 make it easy to incorporate ISO 14001's environmental standards into an existing quality management system (such as ISO 9001). In that regard, Sebhatu and Enquist (2007) suggested that ISO 14001 is mainly a measure of service quality that can be used to promote comprehensive organizational changes that lead to sustainable development and value creation.

So considering, on one hand, that international standards (such as the ISO 14000 EMS) are intended to help improve quality, enhance customer satisfaction, and increase sales, ${ }^{3}$ and, on the other hand, that service experience is directly related to hotel customer satisfaction (Wilkins, Merrilees, and Herington 2007), we analyze ratings of housekeeping accuracy, hotel comfort, hotel services, hotel staff, and the hotel's location and total value. All of those attributes may be considered as "service experience" from the consumer perspective indicators. Thus, we would propose the following hypothesis: 
Hypothesis 2 (H2): Hotels with the ISO 14001 environmental certification receive higher customer ratings regarding the different attributes that measure customer satisfaction compared with hotels without ISO 14001 certification.

To capture preference differences among various customer segments, we analyze the sample according to consumer characteristics, as did Bowie and Buttle (2004), with clients classified into the following six groups: families with older children, families with young children, elderly couples, groups of friends, persons traveling by themselves, and young couples (e.g., Du et al. 2008). Formally, we propose the following hypothesis:

Hypothesis 3 (H3): An unequal influence on the customers' rating of service quality aspects can be observed in hotels environmentally certified through the ISO 14001 standard, depending on the type of customer.

\section{Method and Results}

\section{The Sample}

To explore our research questions, we analyzed guests' ratings of 6,854 Spanish hotels with five, four, or three stars (corresponding to luxury, upscale, and midscale), 350 of which had the ISO 14001 certification. Guests' evaluation data for the year 2011 were retrieved from the hotels' websites and from Booking.com during December 2011. Booking.com provides parallel attribute evaluation for all the hotels, although the number of customers who rate each hotel is different. To ascertain whether the hotel held ISO certification, we sent e-mails to all fourteen certification companies in Spain (although four or five companies certify the majority of the hotels). All but three of the certification companies sent us their list of certified hotels. We also made several web searches to check for possible missing certified hotels. In keeping with our hypotheses, we recorded guests' general evaluation of the hotel and also ratings for housekeeping accuracy, hotel comfort, location, services, staff, and value. For the Booking.com ratings, location refers to convenience, service refers to facilities, staff refers to the quality of the hotel staff, and company size is measured by number of rooms. The database is segmented according to the six different customer segments that we studied, and we also classified hotels by star rating, with the results shown in Exhibit 1.

\section{Data Analysis}

We used analysis of variance (ANOVA) to compare ISO 14001-certified hotels with those that did not have certification, using the following guest satisfaction indicators:
Exhibit 1:

Hotels Sample (Classified by Categories).

\begin{tabular}{lccc}
\hline & $\begin{array}{c}\text { Five-Star } \\
\text { Hotels }\end{array}$ & $\begin{array}{c}\text { Four-Star } \\
\text { Hotels }\end{array}$ & $\begin{array}{c}\text { Three-Star } \\
\text { Hotels }\end{array}$ \\
\hline Without ISO I400I & 23 I & 1,895 & 2,37 I \\
With ISO I400I & 29 & 215 & 70 \\
Total & 260 & 2,110 & $2,44 \mid$ \\
\hline
\end{tabular}

Source. Self-compilation with information retrieved from the internet. Note. Data regarding category were not available for all the samples.

housekeeping accuracy, hotel comfort, and hotel services, value, and location.

After comparing the hotel ratings for properties with ISO 14001 and those without, we split the hotel sample according to the number of stars. Finally, we analyzed the ratings for the six client segments, with the results reported in Exhibit 2.

First, it is worth noting that hotels with ISO 14001 are significantly $(p<.001)$ more expensive and bigger than hotels without this certification. Segmented results by chain scale, or number of stars, are consistent with overall results, although average daily rate (ADR) differences between three-star and five-star hotels were not significant. Generally speaking, though, hotels with ISO 14001 show significantly $(p<.001)$ greater overall value over those without ISO 14001. Over this period, the mean general rating for these properties was .16 higher than those properties without ISO, supporting the primary hypothesis of this article.

Segmented results by scale show significant differences $(p<.001)$ in four-star hotels. While general ratings for three- and five-star hotels with ISO were higher than those without ISO, these differences were not statistically significant.

Splitting the ratings into the component attributes of housekeeping, comfort, location, services, staff, and value, we found significant differences between ISO hotels and noncertified hotels $(p<.001)$ for housekeeping, comfort, location, and services. In particular, four-star hotels with ISO 14001 had significantly higher ratings for these attributes, except for value, which did not show significant differences for this category.

As there is a consensus regarding the reliability of location and services ratings as a measure of clients' satisfaction, we used a classification tree technique to predict or explain responses on each categorical dependent variable (Breiman et al. 1984; Clark and Pregibon 1992; Peña 2002). This approach is a more flexible technique than the classic discriminant technique, so it is better suited to the heterogeneity of this database. The technique uses all available variables and the algorithm selects those variables that contribute most to the discrimination, as well as the cutoff points. 


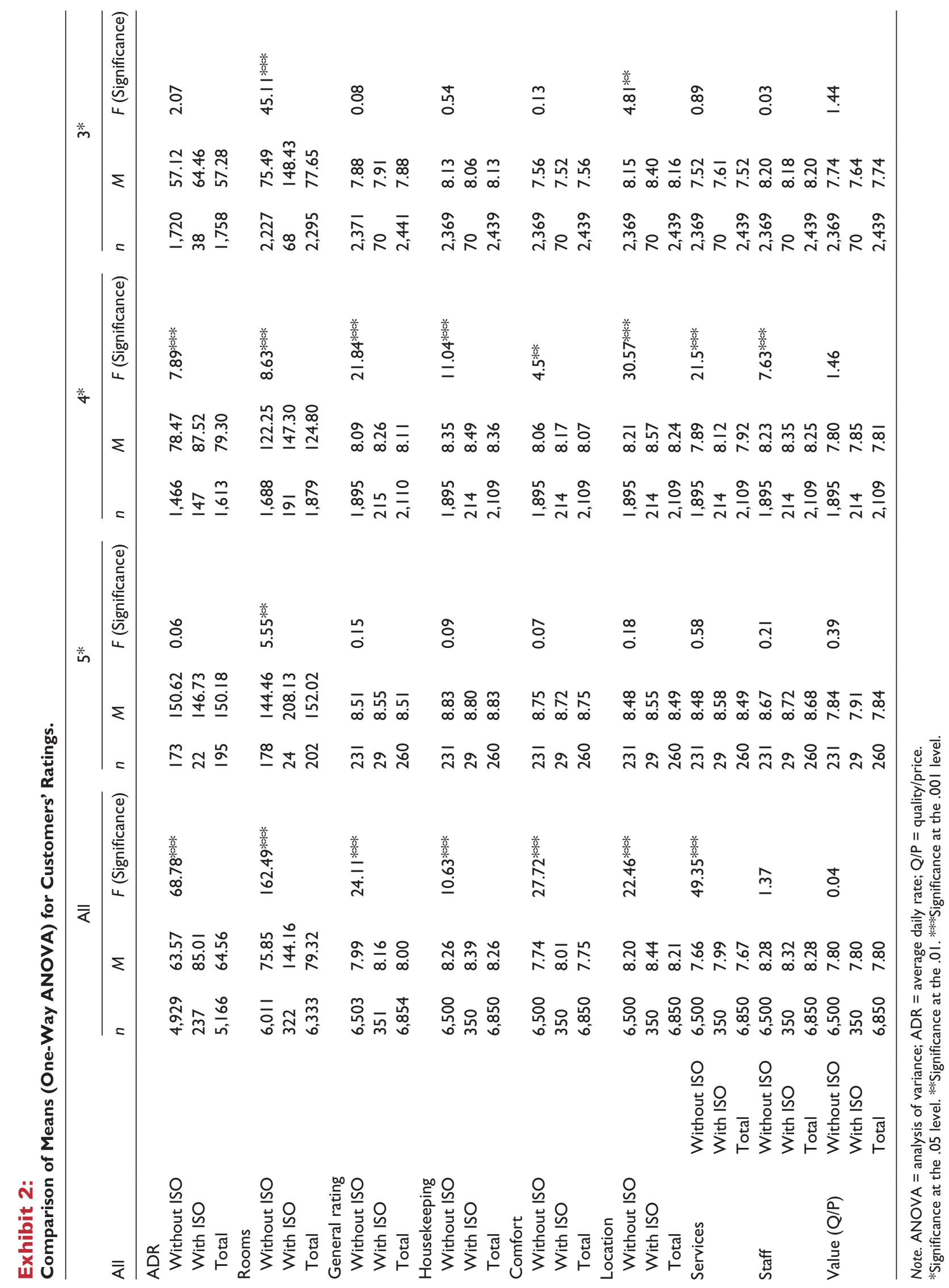




\section{Exhibit 3:}

Classification Tree Considering Hotel Location and Services.

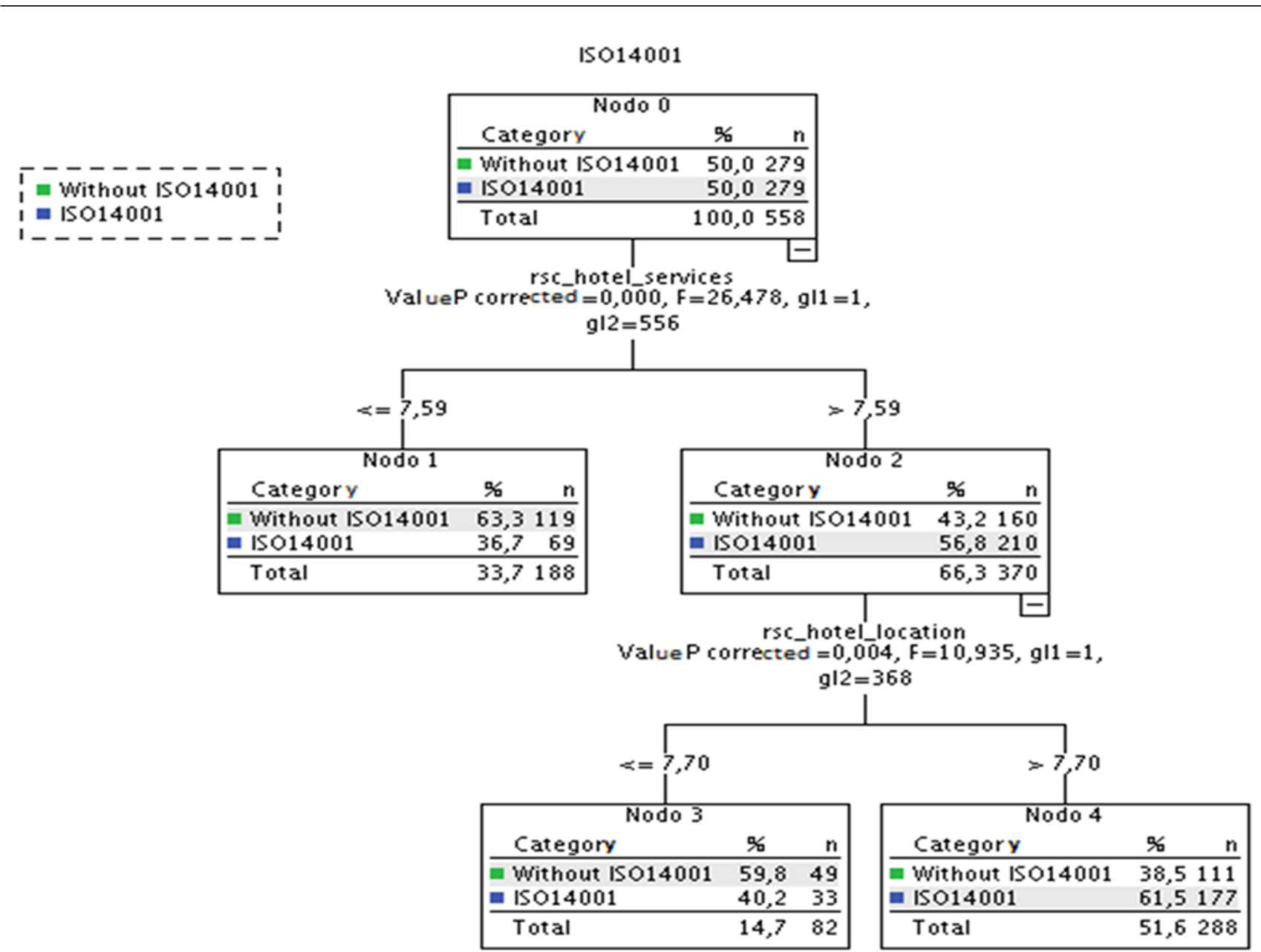

Classification trees allow results to be displayed graphically, as shown in Exhibit 3, making it easier to interpret the results than if only a strict numerical interpretation were used. In our case, after dismissing the hotels that did not provide complete data, we analyzed a total of 5,126 hotels (279 of which were ISO 14001 certified) using the classification tree approach. We selected a random sample among the 4,847 hotels with complete data and noncertified in order not to bias the results (see Exhibit 3).

The mean value for the first selection criterion, customers' services ratings, was 7.59, and a score beneath this value is associated with not having ISO 14001 certification. Two-thirds of the sample scored above 7.59, moving them into the second classification criterion, which is location. Here a value greater than the mean of 7.70 is associated with hotels that have implemented the EMS (ISO 14001). A total of 8 one-way ANOVAs were conducted on each of the different client segments. ANOVA results for each segment are shown in Exhibits 4 to 9.
The overall rating results for the various customer segments were similar to that of the total sample. That is, we found significant differences between certified and noncertified four-star hotels among the various respondent groups, but no significant differences in certified and noncertified five-star hotels. For the three-star hotels, we found few significant differences in the ratings by the various segments. Looking at specific features, the segmented results based on the type of client show generally significant differences $(p<.001)$ for housekeeping and hotel comfort.

Even though it can be seen from the means comparison analysis that hotels that have implemented ISO 14001 have, in general terms, better guest ratings, we cannot determine causality, that is, whether the better ratings result from having implemented the environmental certification system. Overall, these results support the first hypothesis, which stated the contribution of ISO 14001 to value creation in the hotel business by enhancing clients' ratings. Let us look at the implications in more detail. 


\section{Exhibit 4:}

Comparison of Means (One-Way ANOVA) for Customers' Ratings: Families with Older Children.

\begin{tabular}{|c|c|c|c|c|c|c|c|c|c|c|c|c|}
\hline \multirow{2}{*}{$\begin{array}{l}\text { Families } \\
\text { with Older } \\
\text { Children }\end{array}$} & \multicolumn{3}{|c|}{ All } & \multicolumn{3}{|r|}{$5 *$} & \multicolumn{3}{|c|}{$4^{*}$} & \multicolumn{3}{|r|}{$3^{*}$} \\
\hline & $n$ & $M$ & F (Significance) & $n$ & $M$ & F (Significance) & $n$ & $M$ & F (Significance) & $n$ & $M$ & $F$ (Significance) \\
\hline \multicolumn{13}{|l|}{ Housekeeping } \\
\hline Without ISO & 5,510 & 7.87 & $4.32 * *$ & 201 & 8.40 & 0.06 & 1,713 & 7.95 & 2.44 & 2,044 & 7.74 & 1.66 \\
\hline With ISO & 322 & 8.01 & & 24 & 8.46 & & 199 & 8.08 & & 64 & 7.94 & \\
\hline Total & 5,832 & 7.87 & & 225 & 8.41 & & 1,912 & 7.97 & & 2,108 & 7.74 & \\
\hline \multicolumn{13}{|l|}{ Comfort } \\
\hline Without ISO & $5,5 \mid 4$ & 7.34 & $15.14 * * *$ & 201 & 8.20 & 0.23 & 1,715 & 7.67 & $2.95 *$ & 2,042 & 7.16 & 0.64 \\
\hline With ISO & 321 & 7.64 & & 24 & 8.08 & & 199 & 7.81 & & 64 & 7.30 & \\
\hline Total & 5,835 & 7.35 & & 225 & 8.19 & & 1,914 & 7.68 & & 2,106 & 7.17 & \\
\hline \multicolumn{13}{|l|}{ Staff } \\
\hline Without ISO & 5,508 & 7.91 & $3.82 *$ & 201 & 8.26 & 0.05 & $1,7 \mid 4$ & 7.86 & $4.19 * *$ & 2,042 & 7.83 & $3.52 *$ \\
\hline With ISO & 322 & 8.04 & & 24 & 8.21 & & 199 & 8.02 & & 64 & 8.11 & \\
\hline Total & 5,830 & 7.92 & & 225 & 8.26 & & 1,913 & 7.87 & & 2,106 & 7.84 & \\
\hline \multicolumn{13}{|l|}{ Value (Q/P) } \\
\hline Without ISO & 5,506 & 7.40 & 0.38 & 200 & 7.37 & 0.22 & 1,715 & 7.36 & $2.93 *$ & $2,04 I$ & 7.36 & 0.23 \\
\hline With ISO & 322 & 7.44 & & 24 & 7.50 & & 199 & 7.50 & & 64 & 7.44 & \\
\hline Total & 5,828 & 7.40 & & 224 & 7.38 & & 1,914 & 7.37 & & 2,105 & 7.36 & \\
\hline
\end{tabular}

Note. $A N O V A=$ analysis of variance; $\mathrm{Q} / \mathrm{P}=$ quality/price.

*Significance at the .05 level. **Significance at the .01 level. ***Significance at the $.00 \mathrm{I}$ level.

Exhibit 5:

Comparison of Means (One-Way ANOVA) for Customers' Ratings: Families with Young Children.

\begin{tabular}{|c|c|c|c|c|c|c|c|c|c|c|c|c|}
\hline \multirow{2}{*}{$\begin{array}{l}\text { Families with } \\
\text { Young Children }\end{array}$} & \multicolumn{3}{|c|}{ All } & \multicolumn{3}{|r|}{$5 *$} & \multicolumn{3}{|c|}{$4^{*}$} & \multicolumn{3}{|r|}{$3^{*}$} \\
\hline & $n$ & $M$ & F (Significance) & $n$ & $M$ & F (Significance) & $n$ & $M$ & F (Significance) & $n$ & $M$ & $F$ (Significance) \\
\hline \multicolumn{13}{|l|}{ Housekeeping } \\
\hline Without ISO & 5,783 & 8.14 & 0.37 & 206 & 8.77 & 0.18 & $\mathrm{I}, 776$ & 8.20 & 0.45 & 2,134 & 8.04 & 1.98 \\
\hline With ISO & 326 & 8.18 & & 27 & 8.69 & & 201 & 8.25 & & 64 & 7.83 & \\
\hline Total & 6,109 & 8.14 & & 233 & 8.76 & & 1,977 & 8.20 & & 2,198 & 8.03 & \\
\hline \multicolumn{13}{|l|}{ Comfort } \\
\hline Without ISO & 5,785 & 7.66 & $13.22 * * *$ & 207 & 8.70 & 0.33 & $\mathrm{I}, 776$ & 7.98 & 0.68 & 2,134 & 7.51 & 0.2 \\
\hline With ISO & 326 & 7.93 & & 27 & 8.82 & & 201 & 8.04 & & 64 & 7.43 & \\
\hline Total & 6,111 & 7.67 & & 234 & 8.72 & & 1,977 & 7.98 & & 2,198 & 7.50 & \\
\hline \multicolumn{13}{|l|}{ Staff } \\
\hline Without ISO & 5,789 & 8.28 & 0.55 & 207 & 8.66 & 1.11 & $\mathrm{I}, 777$ & 8.21 & 1.88 & 2,135 & 8.24 & 0.51 \\
\hline With ISO & 326 & 8.33 & & 27 & 8.89 & & 201 & 8.30 & & 64 & 8.14 & \\
\hline Total & 6,115 & 8.28 & & 234 & 8.69 & & 1,978 & 8.22 & & 2,199 & 8.23 & \\
\hline \multicolumn{13}{|l|}{ Value (Q/P) } \\
\hline Without ISO & 5,780 & 7.7I & 0 & 207 & 7.87 & 0.78 & $\mathrm{I}, 774$ & 7.74 & 0 & 2,130 & 7.68 & 0.85 \\
\hline With ISO & 326 & 7.7I & & 27 & 8.07 & & 201 & 7.74 & & 64 & 7.53 & \\
\hline Total & 6,106 & 7.7I & & 234 & 7.89 & & 1,975 & 7.74 & & 2,194 & 7.67 & \\
\hline
\end{tabular}

Note. $\mathrm{ANOVA}=$ analysis of variance; $\mathrm{Q} / \mathrm{P}=$ quality/price.

*Significance at the .05 level. **Significance at the .01 level. ***Significance at the .001 level. 
Exhibit 6:

Comparison of Means (One-Way ANOVA) for Customers' Ratings: Elderly Couples.

\begin{tabular}{|c|c|c|c|c|c|c|c|c|c|c|c|c|}
\hline \multirow{2}{*}{$\begin{array}{l}\text { Elderly } \\
\text { Couples }\end{array}$} & \multicolumn{3}{|c|}{ All } & \multicolumn{3}{|r|}{$5^{*}$} & \multicolumn{3}{|c|}{$4 *$} & \multicolumn{3}{|c|}{$3 *$} \\
\hline & $n$ & $M$ & $F$ (Significance) & $n$ & $M$ & F (Significance) & $n$ & $M$ & F (Significance) & $n$ & $M$ & $F$ (Significance) \\
\hline \multicolumn{13}{|l|}{ Housekeeping } \\
\hline Without ISO & 6,368 & 8.34 & $18.02 * * *$ & 229 & 8.88 & 0.25 & 1,876 & 8.43 & $9.57 * * *$ & 2,330 & 8.24 & 0.03 \\
\hline With ISO & 340 & 8.54 & & 28 & 8.94 & & 207 & 8.59 & & 69 & 8.26 & \\
\hline Total & 6,708 & 8.35 & & 257 & 8.88 & & 2,083 & 8.45 & & 2,399 & 8.24 & \\
\hline \multicolumn{13}{|l|}{ Comfort } \\
\hline Without ISO & 6,373 & 7.72 & $34.02 * * *$ & 229 & 8.77 & 0.23 & $\mathrm{I}, 877$ & 8.09 & $3.68 *$ & 2,331 & 7.56 & 0.1 \\
\hline With ISO & 340 & 8.07 & & 28 & 8.84 & & 207 & 8.20 & & 69 & 7.60 & \\
\hline Total & 6,713 & 7.74 & & 257 & 8.78 & & 2,084 & 8.10 & & 2,400 & 7.57 & \\
\hline \multicolumn{13}{|l|}{ Staff } \\
\hline Without ISO & 6,371 & 8.29 & $5 * *$ & 229 & 8.73 & 0 & $\mathrm{I}, 877$ & 8.28 & $4.26 * *$ & 2,332 & 8.23 & 1.45 \\
\hline With ISO & 340 & 8.40 & & 28 & 8.73 & & 207 & 8.39 & & 69 & 8.36 & \\
\hline Total & 6,711 & 8.30 & & 257 & 8.73 & & 2,084 & 8.29 & & $2,40 \mathrm{I}$ & 8.23 & \\
\hline \multicolumn{13}{|l|}{ Value (Q/P) } \\
\hline Without ISO & 6,370 & 7.82 & 1.38 & 229 & 7.87 & 0.35 & $\mathrm{I}, 877$ & 7.88 & 0.68 & 2,332 & 7.77 & 0.81 \\
\hline With ISO & 340 & 7.88 & & 28 & 7.96 & & 207 & 7.93 & & 69 & 7.67 & \\
\hline Total & 6,710 & 7.82 & & 257 & 7.88 & & 2,084 & 7.88 & & 2,401 & 7.77 & \\
\hline
\end{tabular}

Note. $A N O V A=$ analysis of variance; $\mathrm{Q} / \mathrm{P}=$ quality/price.

*Significance at the .05 level. **Significance at the .01 level. ***Significance at the $.00 \mathrm{I}$ level.

\section{Exhibit 7:}

Comparison of Means (One-Way ANOVA) for Customers' Ratings: Group of Friends.

\begin{tabular}{|c|c|c|c|c|c|c|c|c|c|c|c|c|}
\hline \multirow{2}{*}{$\begin{array}{l}\text { Group of } \\
\text { Friends }\end{array}$} & \multicolumn{3}{|r|}{ All } & \multicolumn{3}{|r|}{$5 *$} & \multicolumn{3}{|r|}{$4^{*}$} & \multicolumn{3}{|c|}{$3 *$} \\
\hline & $n$ & $M$ & $F$ (Significance) & $n$ & $M$ & F (Significance) & $n$ & $M$ & F (Significance) & $n$ & $M$ & $F$ (Significance) \\
\hline \multicolumn{13}{|l|}{ Housekeeping } \\
\hline Without ISO & 6,114 & 8.30 & $2.83^{*}$ & 216 & 8.94 & 0.25 & 1,825 & 8.42 & $5.65^{* *}$ & 2,252 & 8.19 & 0.4 \\
\hline With ISO & 331 & 8.40 & & 24 & 8.85 & & 203 & 8.56 & & 67 & 8.11 & \\
\hline Total & 6,445 & 8.31 & & 240 & 8.93 & & 2,028 & 8.43 & & 2,319 & 8.19 & \\
\hline \multicolumn{13}{|l|}{ Comfort } \\
\hline Without ISO & 6,114 & 7.81 & $15.66 * * *$ & 216 & 8.92 & 0.11 & 1,825 & 8.13 & $5.18 * *$ & 2,251 & 7.67 & 0.63 \\
\hline With ISO & 331 & 8.07 & & 24 & 8.86 & & 203 & 8.29 & & 67 & 7.56 & \\
\hline Total & 6,445 & 7.83 & & 240 & 8.92 & & 2,028 & 8.14 & & 2,318 & 7.67 & \\
\hline \multicolumn{13}{|l|}{ Staff } \\
\hline Without ISO & 6,113 & 8.28 & 0.01 & 216 & 8.61 & 0.01 & 1,825 & 8.25 & 1.98 & 2,251 & 8.22 & 0.22 \\
\hline With ISO & 331 & 8.29 & & 24 & 8.59 & & 203 & 8.34 & & 67 & 8.16 & \\
\hline Total & 6,444 & 8.28 & & 240 & 8.61 & & 2,028 & 8.26 & & 2,318 & 8.22 & \\
\hline \multicolumn{13}{|l|}{ Value (Q/P) } \\
\hline Without ISO & 6,109 & 7.98 & 0.11 & 216 & 8.18 & 0.01 & 1,825 & 7.98 & 0.49 & 2,250 & 7.93 & 0.02 \\
\hline With ISO & 331 & 7.96 & & 24 & 8.16 & & 203 & 8.03 & & 67 & 7.91 & \\
\hline Total & 6,440 & 7.98 & & 240 & 8.18 & & 2,028 & 7.99 & & 2,317 & 7.93 & \\
\hline
\end{tabular}

Note. ANOVA = analysis of variance; $\mathrm{Q} / \mathrm{P}=$ quality/price.

*Significance at the .05 level. **Significance at the .0I level. ***Significance at the $.00 \mathrm{I}$ level.

\section{Discussion and Conclusion}

As we said, we found differences in ratings of Spanish hotels with the ISO 14001 label and those that are not so certified. Most interesting, we found significant differences between certified and noncertified hotels in the four-star category, a finding that leads to an intriguing managerial implication. It appears that luxury hotels do not gain distinctive competence in their guests' estimation when they hold the ISO 14001 certification, nor do the middle-scale hotels (three stars) receive a benefit. However, our findings imply that four-star hotels do get important benefits from the clients' point of view when the hotel is environmentally certified. This clearly indicates that four-star hotels have distinct advantages in 


\section{Exhibit 8:}

Comparison of Means (One-Way ANOVA) for Customers' Ratings: Persons Traveling Alone.

\begin{tabular}{|c|c|c|c|c|c|c|c|c|c|c|c|c|}
\hline \multirow[b]{2}{*}{ Persons Traveling Alone } & \multicolumn{3}{|r|}{ All } & \multicolumn{3}{|r|}{$5^{*}$} & \multicolumn{3}{|r|}{$4 *$} & \multicolumn{3}{|r|}{$3^{*}$} \\
\hline & $n$ & $M$ & $F$ (Significance) & $n$ & M & $F$ (Significance) & $n$ & M & $F$ (Significance) & $n$ & M & $F$ (Significance) \\
\hline \multicolumn{13}{|l|}{ Housekeeping } \\
\hline Without ISO & 5,999 & 8.26 & 2.07 & 213 & 8.78 & 0.13 & $\mathrm{I}, 785$ & 8.33 & $3.11 *$ & 2,212 & 8.12 & 0.24 \\
\hline With ISO & 322 & 8.34 & & 27 & 8.71 & & 197 & 8.45 & & 62 & 8.05 & \\
\hline Total & 6,321 & 8.26 & & 240 & 8.77 & & 1,982 & 8.34 & & 2,274 & 8.12 & \\
\hline \multicolumn{13}{|l|}{ Comfort } \\
\hline Without ISO & 6,000 & 7.69 & $13.47 * * *$ & 214 & 8.60 & 0.04 & I,786 & 7.99 & $6.16 * *$ & 2,212 & 7.52 & 0.47 \\
\hline With ISO & 322 & 7.94 & & 27 & 8.56 & & 197 & 8.17 & & 62 & 7.41 & \\
\hline Total & 6,322 & 7.7I & & 241 & 8.60 & & I,983 & 8.01 & & 2,274 & 7.51 & \\
\hline \multicolumn{13}{|l|}{ Staff } \\
\hline Without ISO & 6,003 & 8.22 & 0.08 & 214 & 8.61 & 0.68 & I,787 & 8.13 & $5.77^{* *}$ & 2,212 & 8.13 & 0.65 \\
\hline With ISO & 322 & 8.23 & & 27 & 8.77 & & 197 & 8.29 & & 62 & 8.03 & \\
\hline Total & 6,325 & 8.22 & & 241 & 8.63 & & I,984 & 8.15 & & 2,274 & 8.13 & \\
\hline \multicolumn{13}{|l|}{ Value (Q/P) } \\
\hline Without ISO & 6,002 & 7.79 & 0.77 & 214 & 7.83 & 0.01 & I,788 & 7.73 & 0.45 & 2,211 & 7.7I & 0.46 \\
\hline With ISO & 322 & 7.73 & & 27 & 7.85 & & 197 & 7.78 & & 62 & 7.61 & \\
\hline Total & 6,324 & 7.79 & & 241 & 7.83 & & 1,985 & 7.74 & & 2,273 & 7.7I & \\
\hline
\end{tabular}

Note. ANOVA = analysis of variance; $\mathrm{Q} / \mathrm{P}=$ quality/price.

*Significance at the .05 level. **Significance at the .01 level. ***Significance at the $.00 \mathrm{I}$ level.

\section{Exhibit 9:}

Comparison of Means (One-Way ANOVA) for Customers' Ratings: Young Couples.

\begin{tabular}{|c|c|c|c|c|c|c|c|c|c|c|c|c|}
\hline \multirow[b]{2}{*}{ Young Couples } & \multicolumn{3}{|r|}{ All } & \multicolumn{3}{|r|}{$5 *$} & \multicolumn{3}{|c|}{$4 *$} & \multicolumn{3}{|r|}{$3^{*}$} \\
\hline & $n$ & $M$ & $F$ (Significance) & $n$ & $M$ & F (Significance) & $n$ & $M$ & $F$ (Significance) & $n$ & $M$ & $F$ (Significance) \\
\hline \multicolumn{13}{|l|}{ Housekeeping } \\
\hline Without ISO & 6,432 & 8.17 & $10.53 * * *$ & 229 & 8.76 & 0.02 & 1,879 & 8.28 & $10.8^{* * * *}$ & 2,341 & 8.03 & 1.57 \\
\hline With ISO & 347 & 8.33 & & 28 & 8.78 & & 212 & 8.46 & & 70 & 7.88 & \\
\hline Total & 6,779 & 8.17 & & 257 & 8.76 & & 2,091 & 8.30 & & 2,411 & 8.02 & \\
\hline \multicolumn{13}{|l|}{ Comfort } \\
\hline Without ISO & 6,433 & 7.7I & $16.08 * * *$ & 229 & 8.71 & 0 & 1,879 & 8.05 & $2.73 *$ & 2,342 & 7.52 & 0.45 \\
\hline With ISO & 348 & 7.95 & & 28 & 8.70 & & 213 & 8.15 & & 70 & 7.43 & \\
\hline Total & 6,781 & 7.72 & & 257 & 8.71 & & 2,092 & 8.06 & & $2,4 \mid 2$ & 7.52 & \\
\hline \multicolumn{13}{|l|}{ Staff } \\
\hline Without ISO & 6,432 & 8.23 & 0.25 & 229 & 8.63 & 0.5 & I,879 & 8.18 & $3.96 * *$ & 2,341 & 8.15 & 0.27 \\
\hline With ISO & 347 & 8.26 & & 28 & 8.74 & & 212 & 8.28 & & 70 & 8.09 & \\
\hline Total & 6,779 & 8.23 & & 257 & 8.64 & & 2,091 & 8.19 & & $2,4 I I$ & 8.15 & \\
\hline \multicolumn{13}{|l|}{ Value (Q/P) } \\
\hline Without ISO & 6,432 & 7.69 & 0.23 & 229 & 7.73 & 0.02 & 1,879 & 7.72 & 0.01 & $2,34 I$ & 7.63 & $2.75^{*}$ \\
\hline With ISO & 347 & 7.67 & & 28 & 7.75 & & 212 & 7.73 & & 70 & 7.44 & \\
\hline Total & 6,779 & 7.69 & & 257 & 7.73 & & 2,091 & 7.72 & & $2,4 I I$ & 7.62 & \\
\hline
\end{tabular}

Note. $\mathrm{ANOVA}=$ analysis of variance; $\mathrm{Q} / \mathrm{P}=$ quality/price.

*Significance at the .05 level. **Significance at the .0I level. ***Significance at the .00 l level.

adopting ISO 14001. We can only speculate regarding the reason for this, but an earlier study of Spanish hotels has established the value of ISO 14001 as an aid to effective management (see Segarra-Oña et al. 2012). Most likely, ISO 14001 gives these hotels an opportunity to compete with the five-star hotels through an extra point of differentiation. At the same time, a three-star property may not gain any competitive advantage by adopting ISO 14001 because customers who stay at three-star hotels tend to be more value conscious and may not be willing to pay any extra for ISO 14001 certifications. For the five-star hotels, ISO 14001 certification may be lost in a sea of other luxurious amenities, 
and in any event the properties may have maxed out in guest satisfaction (and ADR), meaning that ISO 14001 would not grant further increase in either measure. That said, given the industry's push toward sustainability, the ISO 14001 certification may give luxury hotels some competitive advantage and allow market share gains against their competitive set.

Regarding the general sample, our results indicate significant differences between the two sets of hotels in guest satisfaction for housekeeping accuracy, hotel comfort, and hotel services. Looking at the results for the guest segments, the satisfaction effect is stronger in hotel comfort and hotel services in all the studied subgroups. In short, guests reward hotels that have the ISO 14001 certification with higher ratings than those that do not have it, fulfilling H1. We encourage hotel marketing decision makers to advertise their active ecofriendly practices to allow environmentally conscious customers make better informed purchasing decisions (Millar 2009; Schubert et al. 2010).

Hotels that have implemented ISO 14001 in Spain are generally larger than those that have not. The mean of the entire sample is 79 employees, while hotels with ISO 14001 averaged 144. Another characteristic of hotels with ISO 14001 is that they have higher room rates. The ADR mean of the entire sample is 64.56 Euros, while hotels with ISO 14001 averaged 85 Euros. At the same time, the certified hotels scored higher on certain features. In the analysis of the sample segmented by type of visitor, after comparing clients' rating of hotels with ISO 14001 and those without, we found significant differences in ratings of comfort, location, and services in all guest segments. In addition, it can be seen that hotels with ISO 14001 show significantly higher rates in cleanliness compared with the whole sample and as judged by families with grown children and by old couples. Thus, H2 was supported. H3 is also fulfilled. Our findings showed that ISO 14001 certification contributes to value creation because clients' ratings are significantly higher in certified hotels. Thus, we consider that ISO 14001 should be a measure of management performance.

These results imply that hotels may be able to get a distinctive asset that leads them to a competitive advantage over similar nonenvironmentally oriented properties if they are ISO 14001 certified, particularly those in upscale market segments. These findings agree with other studies. The results show that hotels with proactive practices exhibited a positive effect on the customers' decision formation (Han, Hsu, and Sheu 2010; Han and Yunhi 2010).

The role that size is playing has also been disentangled; showing that being bigger implies a more formal structure that supports introducing ISO 14001. The most interesting finding is that five-star and three-star hotels do not seem to add any value by having this certification, but four-star guests in this study valued ISO 14001 as a distinctive hotel asset.

Our study confirms that location and services play a critical role in guests' assessment of a hotel, but the study clarifies the additional effect of ISO 14001 certification. We draw this conclusion based on our classification tree, in which we found out that the rates were higher for location and services for the hotels with the ISO 14001 as compared with a random sample of hotels without ISO 14001.

To sum up, our analysis shows that there are significant differences between hotels that have adopted the ISO 14001 proactive environmental management tool from the clients' point of view. However, there is still a research gap in the understanding of what part (or how much) of the higher rankings is due to the implementation of the ISO 14001 and to what extent other attributes are acting as moderating factors.

These results have important managerial implications considering that sustainability is actually one of the main opportunities for the hospitality industry. The results suggest that hotel managers should consider implementing the ISO 14001 EMS. Studies have demonstrated that it not only helps improve productivity and hotel performance but also improves clients' perceptions of the hotel, especially in four-star hotels and in those aspects related to housekeeping accuracy and hotel comfort.

The limitations of this research include the sample, which is limited to the results of Spanish hotels in a single year and does not reflect the evolution of the ratings. Future research will focus on the analysis of larger databases as well as longitudinal studies. An in-depth case qualitative study will be necessary to obtain further information. Another line of research will consist of the analysis of the clients' ratings in other countries, such as France, Italy, the United States, and Asian nations, where guests' assessment of environmental certifications may be entirely different from those in Spain.

\section{Declaration of Conflicting Interests}

The author(s) declared no potential conflicts of interest with respect to the research, authorship, and/or publication of this article.

\section{Funding}

The author(s) disclosed receipt of the following financial support for the research, authorship, and/or publication of this article: The authors would like to thank the Center for Hospitality Research at Cornell University which hosted A. Peiró and M. Segarra as visiting scholars, and the Universitat Politècnica de València for supporting the research project PAID-06-2011-1879.

\section{Notes}

1. www.standardsinfo.net.

2. http://greenhotels.com.

3. www.standardsinfo.net/info/benefits/benefits.html.

\section{References}

Álvarez Gil, M. J., J. Burgos Jiménez, and J. J. Céspedes Lorente. 2001. An analysis of environmental management organizational 
context and performance of Spanish hotels. Omega 29 (6): 457-71.

Anderson, C. (2012). The impact of social media on lodging performance. Cornell Center for Hospitality Research, 12 (15). http://www.hotelschool.cornell.edu/research/chr/pubs/ reports/abstract-16421.html (accessed September 3, 2013).

Bowie, D., and F. Buttle. 2004. Hospitality marketing: An introduction. Oxford, UK: Elsevier Butterworth-Heinemann.

Breiman, L., J. H. Friedman, R. A. Olsen, and C. G. Stone. 1984. Classification and regression trees. Belmont, CA: Wadsworth International Group.

Chan, E. S. W., and S. C. K. Wong. 2006. Motivations for ISO 14001 in the hotel industry. Tourism Management 27: 481-92.

Chan, W. W. 2009. Environmental measures for hotels' environmental management systems: ISO 14001. International Journal of Contemporary Hospitality Management 21 (5): 542-60.

Chan, W. W., and K. Ho. 2006. Hotels' environmental management systems (ISO 14001): Creative financing strategy. International Journal of Contemporary Hospitality Management 18 (4): 302-16.

Clark, L. A., and D. Pregibon. 1992. Tree-based models. In Statistical models in S, ed. J. M. Chambers, and T. J. Hastie, 377-420. Boca Raton, FL: Chapman and Hall.

Claver-Cortés, E., J. F. Molina-Azorín, and J. Pereira-Moliner. 2007. Competitiveness in mass tourism. Annals of Tourism Research 34 (3): 727-45.

D'Souza, C., M. Taghian, and P. Lamb. 2006. An empirical study on the influence of environmental labels on consumers. Corporate Communications: An International Journal 11 (2): 162-73.

Du, L., X. Xu, Y. Cao, and J. Li. 2008. A novel approach to find the satisfaction pattern of customers in hotel management. IEEE International Conference on Fuzzy Systems, 2008. FUZZ-IEEE 2008. (IEEE World Congress on Computational Intelligence), Hong Kong, China.

Dubé, L., C. A. Enz, L. M. Renaghan, and J. Siguaw. 1999. Best practices in the US lodging industry overview, methods, and champions. Cornell Hotel and Restaurant Administration Quarterly 40 (4): 14-27.

Dubé, L., and L. Renaghan. 1999. How hotel attributes deliver the promised benefits. Cornell Hotel and Restaurant Administration Quarterly 40 (5): 89-95.

Ferrari, G., J. Mondéjar-Jiménez, and M. Vargas-Vargas. 2010. Environmental sustainable management of small rural tourist enterprises. International Journal of Environmental Research 4 (3): 407-14.

Font, X. 2002. Environmental certification in tourism and hospitality: Progress, process and prospects. Tourism Management 23 (3): 197-205

Goodman, A. 2000. Implementing sustainability in service operations at Scandic hotels. Interfaces 30 (3): 202-14.

Gunderson, M., M. Heide, and U. Olsson. 1996. Hotel guest satisfaction among business travelers. Cornell Hotel and Restaurant Administration Quarterly 37 (2): 72-81.

Gustin, M., and P. Weaver. 1996. Are hotels prepared for the environmental consumer? Cornell Hotel and Restaurant Administration Quarterly 20 (2): 1-14.

Han, H., L. Hsu, and C. Sheu. 2010. Application of the theory of planned behavior to green hotel choice: Testing the effect of environmental friendly activities. Tourism Management 31 (3): $325-34$

Han, H., and K. Yunhi. 2010. An investigation of green hotel customers' decision formation: Developing an extended model of the theory of planned behavior. International Journal of Hospitality Management 29 (4): 659-68.

Hsieh, Y. 2012. Hotel companies' environmental policies and practices: A content analysis of their web pages. International Journal of Contemporary Hospitality Management 24 (1): 97-121.

Hu, C., and S. Hiemstra. 1996. Hybrid conjoint analysis as a research technique to measure meeting planners' preferences in hotel selection. Journal of Travel Research 35 (2): 62-69.

Hu, H., H. G. Parsa, and J. Self. 2010. The dynamics of green restaurant patronage. Cornell Hospitality Quarterly 51 (3): 344-62.

ISO Central Secretariat. 2009. The ISO 14000 family of international standards. Genève, Switzerland. www.iso.org (accessed August 16, 2013).

Kasim, A. 2009. Managerial attitudes towards environmental management among small and medium hotels in Kuala Lumpur. Journal of Sustainable Tourism 17 (6): 709-25.

Kassinis, G. I., and A. C. Soteriou. 2003. Greening the service profit chain: The impact of environmental management practices. Production and Operations Management 12 (3): 386-403.

Kelly, J., W. Haider, P. Williams, and K. Englund. 2007. Stated preferences of tourists for eco-efficient destination planning options. Tourism Management 28 (2): 377-90.

Klassen, R., and C. McLaughlin. 1996. The impact of environmental management on firm performance. Management Science 42 (8): 1199-1214.

Lee, J., L. Hsu, H. Han, and Y. Kim. 2010. Understanding how consumers view green hotels: How a hotel's green image can influence behavioural intentions. Journal of Sustainable Tourism 18 (7): 901-14.

Lockyer, T. 2003. Hotel cleanliness-How do guests view it? Let us get specific. A New Zealand study. International Journal of Hospitality Management 22 (3): 297-305.

López-Gamero, M. D., E. Claver-Cortés, and J. F. Molina-Azorín. 2011. Environmental perception, management and competitive opportunity in Spanish hotels. Cornell Hospitality Quarterly 52 (4): 480-500.

Matuszak-Flejszman, A. 2009. Benefits of environmental management system in Polish companies compliant with ISO 14001. Polish Journal of Environmental Studies 18 (3): 411-19.

Mensah, I. 2006. Environmental management practices among hotels in the greater Accra region. International Journal of Hospitality Management 25 (3): 414-31.

Millar, M. 2009. A choice model approach to business and leisure traveler's preferences for green hotel attributes. University of Nevada, Las Vegas. http://digitalscholarship.unlv.edu/cgi/ viewcontent.cgi? article $=1952 \&$ context $=$ thesesdissertations (accessed August 16, 2013).

Millar, M., and S. Baloglu. 2011. Hotel guests' preferences for green guest room attributes. Cornell Hospitality Quarterly 52 (3): 302-11.

Ming-Hsiang, C., W. Gon, and H. Jeong. 2005. The impact of macroeconomic and non-macroeconomic forces on hotel stock returns. International Journal of Hospitality Management 24 (2): $243-58$. 
Molina-Azorín, J. F., E. Claver-Cortés, M. D. López-Gamero, and J. J. Tarí. 2009. Green management and financial performance: A literature review. Management Decision 47 (7): 1080-100.

Molina-Azorín, J. F., E. Claver-Cortés, J. Pereira-Moliner, and J. J. Tarí. 2009. Environmental practices and firm performance: An empirical analysis in the Spanish hotel industry. Journal of Cleaner Production 17 (5): 516-24.

Nicholls, S., and S. Kang. 2012. Going green: The adoption of environmental initiatives in Michigan's lodging sector. Journal of Sustainable Tourism 20 (7): 953-74.

Peña, D. 2002. Análisis de datos multivariantes [Multivariate data analysis]. Madrid, Spain: McGraw-Hill.

Ramanathan, R. 2012. An exploratory study of marketing, physical and people related performance criteria in hotels. International Journal of Contemporary Hospitality Management 24 (1): 44-61.

Rodríguez-Antón, J. M., M. Alonso-Almeida, M. Celemín, and L. Rubio. 2012. Use of different sustainability management systems in the hospitality industry. The case of Spanish hotels. Journal of Cleaner Production 22 (1): 76-84.

Sánchez-Ollero, J. L., A. García-Pozo, and A. Marchante-Lara. 2011. The environment and competitive strategies in hotels in Andalusia. Environmental Engineering and Management Journal 10 (12): 1835-43.

Schubert, F., J. Kandampully, D. Solnet, and A. Kralj. 2010. Exploring consumer perceptions of green restaurants in the US. Tourism and Hospitality Research 10 (4): 286-300.

Sebhatu, S. P., and B. Enquist. 2007. ISO 14001 as a driving force for sustainable development and value creation. The TQM Magazine 19 (5): 468-82.

Segarra-Oña, M., A. Peiró-Signes, R. Verma, and L. MiretPastor. 2012. Does environmental certification help the economic performance of hotels? Evidence from the Spanish hotel industry. Cornell Hospitality Quarterly 53 (3): $242-56$.

Sloan, P., W. Legrand, and J. S. Chen. 2012. Sustainability in the hospitality industry. Principles of sustainable operations, 2nd ed. Oxford, UK: Routledge.

Sloan, P., W. Legrand, H. Tooman, and J. Fendt. 2009. Best practices in sustainability: German and Estonian hotels. Advances in Hospitality and Leisure 5:89-107.

Su, C. S., and L. H. Sun. 2007. Taiwan's hotel rating system: A service quality perspective. Cornell Hotel and Restaurant Administration Quarterly 48 (4): 392-401.

Tarí, J. J., E. Claver-Cortes, J. Pereira-Moliner, and J. F. Molina-Azorín. 2010. Levels of quality and environmental management in the hotel industry: Their joint influence on firm performance. International Journal of Hospitality Management 29 (3): 500-10.

Tzschentke, N. A., D. Kirk, and P. A. Lynch. 2008. Going green: Decisional factors in small hospitality operations. International Journal of Hospitality Management 27 (1): 126-33.

Van Rheede, A., R. J. Blomme, and D. M. Tromp. 2010. Exploring the adoption of eco-labels in the Dutch hospitality industry: The impact of government actions and guests expectations. Paper presented at the conference proceedings of the EuroCHRIE, Amsterdam, Netherlands.
Verma, R. 2007. Unlocking the secrets of customers. Cornell Center for Hospitality Research 7 (2). http://www.hotelschool.cornell.edu/research/chr/pubs/reports/abstract-14342. html (accessed September 3, 2013).

Wilkins, H., B. Merrilees, and C. Herington. 2007. Towards an understanding of total service quality in hotels. International Journal of Hospitality Management 26 (4): 840-53.

Wong, K. K. F., and L. Chi-Yung. 2002. Predicting hotel choice decisions and segmenting hotel consumers: A comparative assessment of a recent consumer based approach. Journal of Travel \& Tourism Marketing 11 (1): 17-33.

Zeng, S. X., X. M. Xie, C. M. Tam, and L. Y. Shen. 2011. An empirical examination of benefits from implementing integrated management systems (IMS). Total Quality Management \& Business Excellence 22 (2): 173-86.

Zhang, J. J., N. Joglekar, and R. Verma. 2012a. Exploring resource efficiency benchmarks for environmental sustainability in hotels. Cornell Hospitality Quarterly 53 (3): 229-41.

Zhang, J. J., N. Joglekar, and R. Verma. 2012b. Green moments of truth: Environmental signaling using eco-labels in high contact service systems. Paper presented at the Proceedings of the 12th International Research Conference in Service Management, La Londe, France. http://www.cerog.org/ lalondeCB/SM/2012_lalonde_seminar/papers/28-P1612012-ZHANG-JOGLEKAR-VERMA-REV-26-03-2012. pdf (accessed August 16, 2013).

Zhang, J. J., N. Joglekar, and R. Verma. 2012c. Pushing the frontier of sustainable service operations management: Evidence from US hospitality industry. Journal of Service Management 23 (3): 377-99.

\section{Author Biographies}

Angel Peiró-Signes holds a Ph.D. in business and a degree in industrial engineering (ap479@cornell.edu). He is an assistant professor in analytical accounting and strategic management at the Faculty of Business Administration at the Polytechnic University of Valencia (Spain) and research associate of the Center for Hospitality Research (CHR), Cornell University, USA. He has published several papers at the International Journal of Environmental Research and the Cornell Hospitality Quarterly, among others.

María-del-Val Segarra-Oña is an associate professor of innovation and competitiveness at the Polytechnic University of Valencia (Spain) (maseo@omp.upv.es). She holds a Ph.D. in management and a degree in industrial engineering. She has published papers related to the environmental proactivity of companies and eco-innovation applied to industrial and service sectors at prestigious journals. She is also a research associate of the CHR, Cornell University, USA, and member of the jury of the fortieth anniversary contest of the European Patent Office.

Rohit Verma is a professor of service operations management at the School of Hotel Administration (SHA) (rv54@cornell.edu). He served as the executive director of the CHR, Cornell University, during 2009-2012 and is currently the coordinator of school's MBA-MMH dual degree program initiative. 
José Mondéjar-Jiménez is an associate professor of statistics at the Universidad de Castilla La Mancha (Spain) (Jose.Mondejar@ uclm.es). He is actually the dean of the Social Sciences Faculty at the Cuenca campus. He has been the program chair of the International Conference on Tourism and Environment since its foundation in 2008 .
Manuel Vargas-Vargas is an associate professor of applied statistics at the School of Economics and Business Administration at the Universidad de Castilla La Mancha in Albacete (Spain) (Manuel.Vargas@uclm.es). He has published several papers at prestigious journals and has contributed to more than fifty research conference papers in the environment and business field. 